\title{
Virtual Chemistry Laboratory in Blended Online Learning Mode: The Influence on Students' Motivation and Achievement
}

\author{
Jaslin Ikhsan ${ }^{1}$, Nur Fitriyana ${ }^{2}$, Zulham Arif ${ }^{3}$
}

\footnotetext{
1 Yogyakarta State university, Chemistry Education Department, Faculty of Mathematics and Natural Sciences, 1 Colombo St., ID-55281 Sleman, Yogyakarta, Indonesia, jikhsan@uny.ac.id

2 Yogyakarta State university, Chemistry Education Department, Faculty of Mathematics and Natural Sciences, 1 Colombo Sr., ID-55281 Sleman, Yogyakarta, Indonesia, nur.fitriyana@uny.ac.id

3 Yogyakarta State university, Alumnae of Chemistry Education Master Programme, Faculty of Mathematics and Natural Sciences, 1 Colombo St. ID-55281, Sleman, Yogyakarta, Indonesia
}

Annotation. This study aimed to seek the influence of ViChem-Lab in blended online learning mode towards students' motivation and achievement in chemistry. A quasi-experiment with pre and post-test non-equivalent control group design was implemented. The findings illustrate that the use of ViChem-Lab in blended online learning gives the strongest influence on self-efficacy, curiosity, attention, and satisfaction, respectively, as part of students' motivation. It implied the rise of students' achievement.

Keywords: virtual chemistry laboratory, hands-on laboratory, blended online learning, students' motivation, students' achievement.

\section{Introduction}

The rapid development of science and technology gives significant attention to educators, practitioners, students, and people dealing with the educational field. This development brings a substantial contribution to achieving a 21st-century learning system. The learning instruction in the academic area such as chemistry should be held in interactive, joyful, challenging, and gives sufficient spaces to develop students' rational thinking because it will be implied on strengthening students' motivation in learning chemistry. If a 
student intends to study chemistry that came from either themselves or their environment, they have high motivation to learn chemistry. This motivation predicts students' success in chemistry learning (Ferrel et al., 2016). The stronger students' motivation in learning chemistry, the higher the students' opportunity to be successful in achieving learning outcomes. These students' motivation in chemistry learning is driven by their attention, curiosity, self-efficacy, and satisfaction (Keller \& Kopp, 1987). The attention is related to students' interests. Chemistry teachers should design the chemistry learning activities using a new learning environment to attract students' attention. At the same time, the curiosity of the students in studying chemistry could be challenged by posing problems that should be solved using varied pedagogies. In addition, students' self-efficacy defines students' confidence in underpinning the likelihood for success. Further, the satisfaction allows the students to acquire knowledge in a new setting (Bolte et al., 2013). The four factors, as mentioned earlier, are the driving factors in enhancing students' motivation in chemistry learning. Unfortunately, lowering students' motivation in chemistry learning is still a major problem for chemistry teachers (Wiyarsi et al., 2017). Güvercin et al. (2010) stated that students' motivation to learn science, i.e., chemistry, declines as the grade level increases. Thus, to increase students' motivation in chemistry, it needs an interesting teaching method, practical work, utilization of technology, and a joyful educational environment (Augustinovič, 2019).

Recent studies have been implemented varied treatments as an effort to improve students' motivation in learning chemistry, e.g., info technology in chemistry (Zhikina \& Portjanskaya, 2007); problem-based learning (Demirel \& Turan, 2010); home experiments (Gendjova, 2007); distance learning technologies (Abakumova et al., 2016); Hermann whole brain teaching (Bawaneh et al., 2011); inquiry-based teaching (Pečiuliauskiene \& Belakoz, 2019); and collaborative learning based Science, Technology, Society, and Engineering (Priyambodo et al., 2021). Those studies have been focused on using technology and students-centred learning paradigm. Thus, the development of technology contributes to the enhancement of students' skills, cognitive characteristics, and motivation (Stošić, 2015). A media that provides the relevance of chemistry and technology needs to be implemented to enhance students' motivation.

On the other hand, students' motivation became a significant predictor of students' chemistry achievement (Akbas \& Kan, 2007). However, the decline of students' achievement in chemistry may cause by the nature of the chemistry concept. Since the chemistry lesson is one of the science subjects that required comprehensive and systemic thinking, thus mostly high school students considered chemistry a difficult subject. This difficulty is caused by the abstractness concept of chemistry (Sirhan, 2007; Sokrat et al., 2014), the multiple representation properties of chemistry (Sirhan, 2007; Treagust et al., 2000; Salta \& Tzougraki, 2004), and the need of reasoning skills (Coll et al., 2005). Furthermore, regarding the nature of the chemistry concept, laboratory work activities have a pivotal role in chemistry learning instruction (Elliot et al., 2008). The laboratory work activities 
aim to support the reasoning and understanding of naturally abstract chemistry concepts. Unfortunately, the chemistry laboratory work activities face many preparation challenges until its implementation. The challenges include: the lack of tools and materials, the limited allocation of learning time in the school, the unavailability of laboratory technicians, and expensive tools and materials used in the chemistry laboratory. Still, many students show their negative feelings toward the hands-on laboratory activities (Spagnoli et al., 2016) due to the limitation of laboratory activities they have performed. Therefore, such limitations of the hands-on laboratory could be overcome by instructional media that can interpret laboratory work activities, i.e., Virtual Chemistry Laboratory (ViChem-Lab).

ViChem-Lab can be defined as a series of computer programs that visualize abstract phenomena or complex experiments performed in real laboratories (Tatli \& Ayas, 2013). Therefore, the ViChem-Lab can enhance the learning activities to develop students' problem-solving skills, especially in chemistry. ViChem-Lab plays as a supporting media in gaining new experiences, and it can motivate students to actively participate in the experimental work (Ardac \& Akaygun, 2004). The ViChem-Lab provides meaningful experiences for students due to its important concepts, principles, and learning process in chemistry. Through the ViChem-Lab, students have the opportunity to repeat the experimental simulation and deeply explore its chemistry concept. The ViChem-Lab contains an interactive simulation of chemistry experiments; hence, it will attract students' interest and attention, increasing their motivation to learn chemistry. However, the effectiveness of that media in chemistry learning was still debated, although several studies have been proven that ViChem-Lab is the potential to improve student's learning outcomes, as suggested by Latifah et al. (2018); Wijayanti et al. (2019); and Solikhin et al. (2019). Moreover, previous studies describe that the ViChem-Lab as supplement brings an enhancement of students' achievement (Špernjak \& Šorgo, 2017; Bozkurt, 2008); self-efficacy (Dyrberg et al., 2016); attitude (Dyrberg, et al., 2016); and students' independence (Latifah et al., 2018). Furthermore, the use of ViChem-Lab is increasing since the hands-on laboratory work was so costly much (Hawkins \& Phelps, 2013). Unfortunately, many chemistry teachers still act skeptical about the effectiveness of ViChem-Lab. Therefore, the research investigating the application of ViChem-Lab on chemistry learning towards students' attitude, i.e., motivation and students' cognitive, i.e., achievement in chemistry, is needed.

Phrased differently, the advancement of technology led the teaching-learning instruction to be held through the combination of face-to-face and online learning instruction. This learning instruction is called blended online learning (Lalima \& Dangwal, 2017; Musawi, 2011; Jahjouh, 2014). In blended online learning, all curriculum prepared in an online class with some classes take place in the face-to-face learning mode that corresponds with the agreement among students and teachers (Volungevičienè et al., 2020). The lectures combine physical and digital methods organized in the same location, either in the digital or physical, with the same conditions and intensity. Thus, blended 
online learning integrates innovation and technological progress through an online learning system with the interaction and participation of traditional learning mode. The blended online learning mode evolved as an effective learning activity with a technologyenhanced online setting (Baragash \& Al-Samarraie, 2018; Bidara, 2016). Blended online learning offers many advantages, such as providing students' learning-centered, increasing students' learning engagement and ease of use, improving learning independence, and growing learning flexibility (Volungevičiene et al., 2020; Zacharis, 2015). The role of blended online learning is potential to predict students' satisfaction as an outcome (Kintu, 2017). Therefore, the emerging use of blended online learning that combines with ViChem-Lab is promising.

Since the ViChem-Lab in this research can be found on mobile phones or computer devices thus, it can be accessed through online and offline learning modes. The ViChem-Lab was provided in the online phase in the Modular Object-Oriented Dynamic Learning Environment (Moodle). The Moodle is a platform mostly used to supplement face-to-face learning at blended online learning mode (Sharma et al., 2019). As suggested by Gulbinskiene et al. (2017), Moodle platform helps to develop metacognitive awareness and fosters students' learning independence. The students could feel free to repeat the experimental simulation anywhere and anytime through their own devices. Thus, it significantly improves students' understanding of the chemistry concept. Furthermore, online learning leads the online discussion one with another were improved. The students could prepare the face-to-face learning instruction well, which increases students' achievement. Accordingly, the existence of this instructional media could enhance the utilization of technology-based media (Calimag et al., 2014). Thus, the ViChem-Lab offers a new learning environment that signifies students' motivation is improving. A better student motivation will increase students' strong desire to reach their targets, which will be implied in students' achievement (Suyatno et al., 2019).

Therefore, this research is concerned to seek the influence of ViChem-Lab in blended online learning mode on students' motivation and achievement toward chemistry. It should be promising since the ViChem-Lab provides effective interactive media as a supplement or replacement for the chemistry laboratory work in the learning instruction. Moreover, the presence of blended online learning gives extra learning time and learning material for students that makes a flexible learning instruction were held (Fitriyana et al., 2021; Wiyarsi et al., 2019).

\section{Research Focus and Questions}

Along with the development of science and technology in the 21st-century learning system, the construction of ViChem-Lab offers an alternative way in the chemistry laboratory work. Many researchers in the chemistry learning area are focused on developing 
the media of ViChem-Lab. Despite the effectiveness of ViChem-Lab as the supplement or replacement of the hands-on laboratory activities still controversial, many studies reported it is as potential media. Thus, the study that seeks the effectiveness of ViChem-Lab as media in the chemistry laboratory work is still significant to be investigated.

In this research, the ViChem-Lab was used to supplement the chemistry learning activities. It contains an interactive simulation of chemistry experiments; hence, it will attract students' interest and attention toward chemistry, enhancing students' motivation to learn chemistry. Moreover, the ViChem-Lab is provided in the Moodle, and thus with a blended online learning mode, students were easily flexibly accessing the ViChem-Lab. They can freely repeat the chemistry experiment simulation every time and everywhere, which significantly improves students' understanding of chemistry concepts. Furthermore, online learning leads the online discussion with another enhanced. The students became well prepared in the face-to-face learning instruction; thus, their achievement improved. Through the online phase of blended online learning, the students prepare the laboratory report through the online learning platform. According to the aforementioned discussion, this research's sole objective is to investigate the influence of ViChem-Lab in blended online learning mode on students' motivation and achievement toward chemistry. The research questions below are elaborated to lead this study.

Question one: How was the profile of students' motivation toward chemistry in applying ViChem-Lab compared with the Hands-on Lab?

Question two: Is there any significant difference in students' motivation among ViChem-Lab group and the Hands-on Lab group?

Question three: How was the profile of students' achievement toward chemistry in applying ViChem-Lab compared with the Hands-on Lab?

Question four: Is there any significant difference in students' achievement among ViChem-Lab group and the Hands-On Lab group?

\section{Methodology of Research}

\section{Design of Research}

This research aimed to investigate the influence of the use of ViChem-Lab in blended online learning mode on the two different dependent variables, namely students' motivation and achievement toward chemistry. It is implemented in the chemistry lesson with the topic of electrolyte and non-electrolyte solution and redox reaction. A quasi-experiment with pre-test and post-test non-equivalent control group design was employed in this research. Therefore, two types of student groups were enrolled in this research, the experimental and control groups. The experimental group was devoted to using ViChem-Lab while the control one used a hands-on lab. Moreover, the pre-post 
design requires the data of students' motivation and achievement were collected before and after the treatment. The research design of this study is seen in Table 1.

Table 1

Research Design

\begin{tabular}{lcc}
\hline \multirow{2}{*}{ Variable } & \multicolumn{2}{c}{ Student Group } \\
\cline { 2 - 3 } & Experimental & Control \\
\hline Research Treatment & $\begin{array}{c}\text { ViChem-Lab in blended } \\
\text { online learning } \\
\text { Pre-test }\end{array}$ & $\begin{array}{c}\text { Hands-on laboratory in } \\
\text { face-to-face learning }\end{array}$ \\
Students' Motivation Questionnaire & Yes & Yes \\
Students' Achievement Test & Yes & Yes \\
Students' Motivation Questionnaire & Post-test & Yes \\
Students' Achievement Test & Yes & Yes \\
\hline
\end{tabular}

\section{Sample of Research}

Two different student groups were used in this research: the experimental and control groups. The experimental group used ViChem-Lab in blended online learning (referred to as ViChem-Lab group henceforth). In contrast, the control group implemented a hands-on laboratory in face-to-face learning (called as hands-on group hereafter). The two student groups consist of 33 students and 30 students, respectively, for ViChem-Lab and Hands-on groups. These two groups were drawn from a public secondary high school in Sleman Regency, Yogyakarta, Indonesia, as the population. The students have similar characteristics such as the age around 15 years old, enrolled in science program of secondary school, and has suitable facilities in conducting blended online learning.

Furthermore, the two student groups were enrolled in the tenth grade and selected through cluster random sampling technique. Before establishing the research samples, the student's prior knowledge analysis was conducted through one-way ANOVA technique. The collected data of previous knowledge using the formative test in the chemical bonding material of chemistry. The analysis shows that there was no significant difference in students' prior knowledge of a total of 5 groups in the population (Sig. found to be $>0.05$ significant level). Thus, the researcher randomly picked two student groups as the research samples in this study. The two student groups were voluntarily agreed as part of the research sample in this study. 


\section{Data Collection Tools}

Two dependent variables, the students' motivation and achievement toward chemistry, were collected. The data of students' motivation was collected using Students' Motivation Questionnaire (SMQ), while the data of students' achievement were obtained through Students' Achievement Test (SAT). The SMQ and SAT were administered before and after the research treatment given on both student groups. The researchers well developed these two data collection tools.

\section{Student Motivation Questionnaire (SMQ)}

The SMQ was used to determine the level of students' motivation in chemistry learning activities. The SMQ was developed according to the indicator of motivation covering the aspect of attention, curiosity, self-efficacy, and satisfaction. The SMQ consists of 20 items statements with a Likert-type scale ranging from always that signified 4 points to never that implied 1 point.

The validity and reliability of SMQ were carried out before it was used to collect students' motivation data. The SMQ employs face, content, and empirical validity. A group of experts was confirmed the face and content validity of SMQ. They gave feedback to improve the quality of SMQ in terms of appropriateness of the motivation content, the suitability of the items with the indicators to be achieved, and the correct Indonesian grammar procedures. After necessary revision, according to the experts' feedback, the SMQ was administered to a total of 66 students out of the research samples to obtain empirical validity. These data were analysed, and it was found that a number of 20 items of SMQ were empirically valid. Furthermore, from these data, the reliability of SMQ was calculated, and it was found to be intensely reliable with the Cronbach Alpha value of 0.753 (Gruilford, 1978). Therefore, the SMQ could be used as reliable tool to obtain students' motivation data. The SMQ indicators distribution is shown in Table 2.

After the SMQ was confirmed as useful and reliable tool to obtain the data of students' motivation, this SMQ was distributed into the sample before and after the experimental manipulation have been implemented on both student groups. Through paper and pencil administration, the research samples need to fulfill the SMQ. They were told that the results of the SMQ was not affected the final grade of the chemistry lesson. Moreover, the identity of the respondent was also kept a secret. Therefore, the students were asked to fill the SMQ honestly following their experience and feeling in this context.

\section{Students' Achievement Test (SAT)}

The SAT was used to measure the pre-test and post-test on the chemistry concept of electrolyte and non-electrolyte solution and redox reaction. The SAT aimed to determine the eliciting of students' achievement after the experimental manipulation given to the two student groups enrolled in this research. The SAT consists of multiple-choice questions with a total of 5 alternative answers. It was constructed following the cognitive level of revised Bloom Taxonomy covering remembering (C1), knowing (C2), applying (C3), analyzing (C4), evaluating (C5), and creating (C6) (Karthwohl, 2002). 
Table 2

SMQ Indicators Distribution

\begin{tabular}{clcl}
\hline Aspect & \multicolumn{1}{c}{ Indicators } & $\begin{array}{c}\text { Total of } \\
\text { Items }\end{array}$ & \multicolumn{1}{c}{ Sample of Item } \\
\hline Attention & $\begin{array}{l}\text { Giving attention in dealing } \\
\text { and preparing chemistry } \\
\text { learning activities }\end{array}$ & 5 & $\begin{array}{l}\text { I will discuss the chemistry learning ma- } \\
\text { terial with my friend even though it is out } \\
\text { of the school's chemistry learning time }\end{array}$ \\
Curiosity & $\begin{array}{l}\text { Expending high enthusiasm } \\
\text { in understanding chemistry } \\
\text { concept }\end{array}$ & 5 & $\begin{array}{l}\text { I am actively involved in searching for } \\
\text { any references that support chemistry } \\
\text { learning material }\end{array}$ \\
Self-efficacy & $\begin{array}{l}\text { Using more effort in master- } \\
\text { ing chemistry concept }\end{array}$ & 5 & $\begin{array}{l}\text { I feel challenges to master the difficult } \\
\text { chemistry concept }\end{array}$ \\
Satisfaction & $\begin{array}{l}\text { Showing good impression } \\
\text { toward chemistry learning } \\
\text { activities }\end{array}$ & 5 & $\begin{array}{l}\text { I feel satisfied with the chemistry learn- } \\
\text { ing instruction held by my teacher }\end{array}$ \\
\hline Total & 20 & \\
\hline
\end{tabular}

The initial of the SAT consists of a number of 40 multiple-choice questions. Before using the SAT to collect the data of students' achievement, the validity and reliability of SAT were calculated. The validity of SAT was conducted through the face, content, and empirical validity. The face and content validity of SAT was obtained by asking experts' judgments regarding the appropriateness of chemistry content and item conformity with the indicator to be achieved. Feedback from the experts was considered, and necessary revision was made to improve SAT quality. After the correction was made, the experts declared that the SAT has a good face and content validity.

Furthermore, the SAT that has been stated to have a good face and content validity was then administered to a total of 60 students out of the research samples which have completed the electrolyte and non-electrolyte solution and redox reaction materials. It aims as the requirement of the empirical validity. This empirical validity was conducted through a paper and pencil test, and the results were analyzed following the correlation of Biserial Point (Wiersma \& Jurs, 1990). After the analysis, it yielded that a number of 30 multiple choice questions were valid. It represented the indicators and competency achievement of electrolyte and non-electrolyte and redox reaction topics; therefore, as many as 30 multiple choice questions of SAT were used to collect the data of students' achievement in this research.

In addition, the reliability of the SAT was analyzed through the result of empirical validity data. The analysis followed the Kuder Richardson-20 test. The analysis results show that the SAT was highly reliable, with the value of Cronbach's alpha reliability found to be 0.767 . It means that the SAT has strong category reliability (Gruilford, 1978), and it can be used as a reliable instrument to obtain the data of students' achievement in this research. The distribution of SAT indicators with the cognitive levels according to the revised Bloom Taxonomy are illustrated in Table 3. 


\section{Experimental Manipulation}

The implementation of ViChem-Lab in blended online learning was held for eight meetings teaching-learning activities. The experimental manipulation given in the experimental class was ViChem-Lab in blended online learning. The blended online learning provides the possibilities in conducting online and face-to-face learning. Hence the ViChem-Lab group held the chemistry learning activities in two ways, online and face-to-face phase. As a comparison, the control class employs a hands-on laboratory in face-to-face learning, the usual chemistry teaching-learning instruction. The comparison of the experimental manipulation perceived in both classes is shown in Table 4 .

\section{Table 3}

The Distribution of SAT Indicators

\begin{tabular}{lcccc} 
& \multicolumn{3}{c}{ SAT Content Knowledge } & \multicolumn{3}{c}{ Number of items on the } \\
& Cognitive Level & \\
& C1 & C2 & C3 & C456 \\
\hline $\begin{array}{l}\text { Properties of electrolyte and non-electrolyte solution } \\
\text { The cause of electrolyte solution conducts electricity }\end{array}$ & 1 & 1 & 2 & \\
$\begin{array}{l}\text { Classification of solutions based on their properties in } \\
\text { conducting electricity }\end{array}$ & 3 & 1 & 1 \\
$\begin{array}{l}\text { The type of compound of electrolyte solution } \\
\text { The concept of redox reaction }\end{array}$ & 1 & 2 & 2 & 2 \\
Redox reaction equation & & & 1 & 5 \\
\hline Total & 2 & 10 & 9 & 9 \\
\hline
\end{tabular}

Table 4

Experimental Manipulation

\begin{tabular}{|c|c|c|}
\hline Student Group & ViChem-Lab Group & Hands-On Group \\
\hline $\begin{array}{l}\text { Face-to-face } \\
\text { learning }\end{array}$ & $\begin{array}{l}\text { Learning the concept of electrolyte } \\
\text { and non-electrolyte solution and } \\
\text { redox reaction topic } \\
\text { Laboratory work activities using } \\
\text { hands-on and enrichment using } \\
\text { ViChem-Lab simulation } \\
\text { Discussion } \\
\text { Presentation }\end{array}$ & $\begin{array}{l}\text { Learning the concept of electrolyte } \\
\text { and non-electrolyte solution and re- } \\
\text { dox reaction topic } \\
\text { Laboratory work activities using } \\
\text { hands-on laboratory } \\
\text { Discussion } \\
\text { Presentation } \\
\text { Written reporting of the laboratory } \\
\text { work activity }\end{array}$ \\
\hline Online learning & $\begin{array}{l}\text { Online discussion } \\
\text { Online reporting of the laboratory } \\
\text { work activity } \\
\text { Repeating the ViChem-Lab simulation }\end{array}$ & - \\
\hline
\end{tabular}


In this research, the ViChem-Lab is provided in the Moodle; hence it can be accessed before the students deal with face-to-face or online learning instruction. The utilization of ViChem-Lab was initiated in face-to-face learning under teacher supervision. Since the ViChem-Lab was prepared in the Moodle, the students in ViChem-Lab group could easily repeat the experimental simulation they did in the face-to-face phase. Hence, the students will enrich their knowledge and their understanding of chemistry concepts regarding the experimental they performed. Moreover, the online stage of blended online learning improves students' interactions through the online discussion forum with the teacher or their peers. In addition, the students reported the experimental simulation they perceived through ViChem-Lab in the online session. The illustration of ViChem-Lab used in this research is depicted in Figure 1.

\section{Figure 1.}

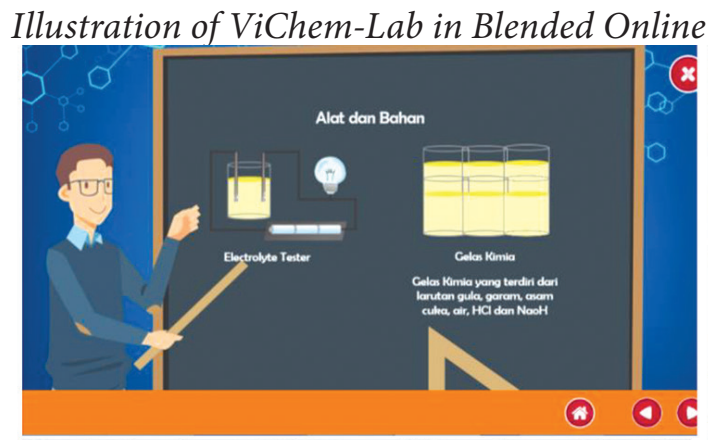

\section{Learning}

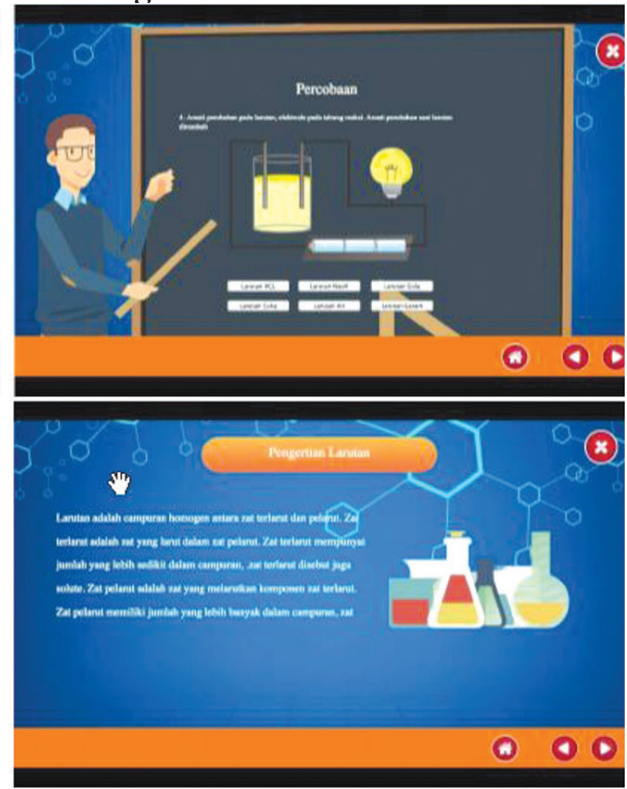

On the other hand, the hands-on group as a comparison class, performing the laboratory work activities using hands-on laboratory, the usual facilities to experience laboratory work in the chemistry instruction. The students participated in the laboratory work in a small group of 3-4 students. Hence, they work in a small collaborative group. The discussion among teachers and students is held in the school's face-to-face learning when the teacher has spare time. The reporting of the laboratory activities conducts in written form. The students should submit their reporting a week after the experiment has been conducted. 


\section{Data Analysis}

The study was implemented towards two groups focused on their motivation and achievement. Since the data of students' motivation belongs to ordinal data, thus Mann-Whitney U test was used to determine the significant influence of teaching intervention on students' motivation among the two groups. At the same time, the Independent Sample T-Test was used to determine its effects on students' achievement. The normality and homogeneity test were performed towards the students' achievement data as the prerequisite of the independent sample t-test analysis. In addition, the profile of students' motivation and achievement toward chemistry were explored through descriptive statistics. Moreover, to determine the profile of the improvement of students' motivation and achievement toward chemistry, the normalized n-gain category analysis was used. It was calculated by categorizing the $\mathrm{n}$-gain of students' motivation and achievement toward chemistry as high ( $\mathrm{n}$-gain $>0.7$ ), medium $(0.7 \geq \mathrm{n}$-gain $\geq 0.3)$, and low (n-gain $<0.3)$ following Hake (1998).

\section{Findings of Research}

The findings of this research are presented in this section. The descriptive statistics of students' motivation and achievements, such as the number of students, ideal score, mean score, and standard deviation, are depicted in Table 5.

Examining the data in Table 5, the ViChem-Lab group gives a better result in students' motivation and achievement toward chemistry than the hands-on group. Both groups experienced a significant improvement in students' motivation and achievement before and after the experimental manipulation. However, the ViChem-Lab group brings a better enhancement on the two variables aforementioned.

Table 5

The Descriptive Statistics

\begin{tabular}{|c|c|c|c|c|c|c|c|c|}
\hline \multirow{3}{*}{ Parameter } & \multicolumn{4}{|c|}{ Students' Motivation } & \multicolumn{4}{|c|}{ Students' Achievement } \\
\hline & \multicolumn{2}{|c|}{$\begin{array}{l}\text { ViChem- } \\
\text { Lab Group }\end{array}$} & \multicolumn{2}{|c|}{$\begin{array}{c}\text { Hands- } \\
\text { On Group }\end{array}$} & \multicolumn{2}{|c|}{$\begin{array}{l}\text { ViChem- } \\
\text { Lab Group }\end{array}$} & \multicolumn{2}{|c|}{$\begin{array}{c}\text { Hands- } \\
\text { On Group }\end{array}$} \\
\hline & Pre-test & Post-test & Pre-test & Post-test & Pre-test & Post-test & Pre-test & Post-test \\
\hline Number of students & 33 & 33 & 30 & 30 & 33 & 33 & 30 & 30 \\
\hline Ideal Score & 80 & 80 & 80 & 80 & 100 & 100 & 100 & 100 \\
\hline Mean Score & 39.88 & 66.12 & 50.49 & 61.97 & 30.55 & 83.76 & 30.07 & 79.90 \\
\hline Std. Dev. & 5.31 & 3.65 & 7.43 & 5.27 & 11.93 & 4.26 & 10.16 & 4.96 \\
\hline
\end{tabular}

It can be implied that the ViChem-Lab in blended online learning mode gave a more substantial effect than the hands-on laboratory in face-to-face learning. Furthermore, 
the profile of students' motivation according to the results of n-gain category analysis on the two groups is shown in Tables 6.

Table 6

The Profile of Students' Motivation Toward Chemistry

\begin{tabular}{|c|c|c|c|c|c|c|}
\hline \multirow[t]{2}{*}{ Dependent Variable } & \multicolumn{4}{|c|}{ Vi-Chem-Lab Group } & \multicolumn{2}{|c|}{ Hands-on Group } \\
\hline & \multicolumn{2}{|c|}{ n-gain } & \multicolumn{2}{|c|}{ Category n-gain } & n-gain & Category n-gain \\
\hline Students' motivation & \multicolumn{2}{|c|}{0.65} & \multicolumn{2}{|c|}{ Medium } & 0.35 & Medium \\
\hline Attention & \multicolumn{2}{|c|}{0.56} & \multicolumn{2}{|c|}{ Medium } & 0.26 & Low \\
\hline Curiosity & \multicolumn{2}{|c|}{0.66} & \multicolumn{2}{|c|}{ Medium } & 0.39 & Medium \\
\hline Self-efficacy & \multicolumn{2}{|c|}{0.85} & \multicolumn{2}{|c|}{ Medium } & 0.64 & Medium \\
\hline Satisfaction & \multicolumn{2}{|c|}{0.56} & \multicolumn{2}{|c|}{ Medium } & 0.20 & Low \\
\hline \multicolumn{7}{|c|}{ The profile of students' motivation according n-gain category analysis } \\
\hline & \multicolumn{6}{|c|}{ N-Gain Level } \\
\hline & \multicolumn{3}{|c|}{ Vi-Chem-Lab Group } & \multicolumn{3}{|c|}{ Hands-on Group } \\
\hline & High & Medium & Low & High & Medium & Low \\
\hline Students' motivation & $30 \%$ & $70 \%$ & $0 \%$ & $10 \%$ & $50 \%$ & $40 \%$ \\
\hline Attention & $21 \%$ & $76 \%$ & $3 \%$ & $7 \%$ & $47 \%$ & $47 \%$ \\
\hline Curiosity & $55 \%$ & $33 \%$ & $9 \%$ & $7 \%$ & $60 \%$ & $33 \%$ \\
\hline Self-efficacy & $82 \%$ & $18 \%$ & $0 \%$ & $43 \%$ & $43 \%$ & $13 \%$ \\
\hline Satisfaction & $18 \%$ & $76 \%$ & $6 \%$ & $0 \%$ & $40 \%$ & $60 \%$ \\
\hline
\end{tabular}

As seen in Table 6, it was clearly depicted that the students' motivation was improving since the value of $\mathrm{n}$-gain on the two groups has a positive value. Still, the results of n-gain category analysis in the ViChem-Lab group were better than the hands-on group. The value of n-gain on each indicator of students' motivation in the ViChem-Lab group was signified into a medium category with the highest value found on the self-efficacy indicator. A same result was found on the hands-on group that self-efficacy is one of the indicators of students' motivation that gives the most substantial influence. However, the ViChem-Lab group provides greater improvement than the hands-on group. Similar results were found on the profile of students' achievement (see Table 7). The two groups signified a high category of n-gain. However, the ViChem-Lab indicated a stronger enhancement in students' achievement. Therefore, the ViChem-Lab strongly influences students' motivation and achievement among the two groups of this research.

In addition, to examine the significant differences in students' motivation and achievement among the two groups, the Mann-Whitney $\mathrm{U}$ test and Independent T-test analysis was performed. The Mann-Whitney $U$ test determining the significant differences in students' motivation was presented in Table 8. 
Table 7

The Profile of Students' Achievement Toward Chemistry

\begin{tabular}{lcccc}
\hline \multirow{2}{*}{$\begin{array}{c}\text { Dependent } \\
\text { Variable }\end{array}$} & \multicolumn{2}{c}{ Vi-Chem-Lab Group } & \multicolumn{2}{c}{ Hands-on Group } \\
\cline { 2 - 4 } & n-gain & Category n-gain & n-gain & Category n-gain \\
\hline Students' achievement & 0.76 & High & 0.71 & High \\
\hline \multicolumn{2}{c}{ The profile of students' } & achievement according n-gain category analysis \\
\hline \multirow{2}{*}{ Interval } & \multirow{2}{*}{ Level } & \multicolumn{2}{c}{ Students' Group } \\
\cline { 3 - 5 } & & Vi-Chem-Lab Group & Hands-on Group \\
\hline n-gain $>0.7$ & High & $75.76 \%$ & $53.33 \%$ \\
$0.7 \geq$ n-gain $\geq 0.3$ & Medium & $24.24 \%$ & $46.67 \%$ \\
n-gain $<0.3$ & Low & $0 \%$ & $0 \%$ \\
\hline
\end{tabular}

Table 8

Mann-Whitney U Test Determining the Significant Differences on Students' Motivation

\begin{tabular}{lccccccr}
\hline $\begin{array}{c}\text { Dependent } \\
\text { Variable }\end{array}$ & Mean & $S D$ & $\begin{array}{c}\text { Student } \\
\text { Group }\end{array}$ & $\begin{array}{c}\text { Mean } \\
\text { Rank }\end{array}$ & $\begin{array}{c}\text { Sum of } \\
\text { Ranks }\end{array}$ & $\begin{array}{c}\text { Mann } \\
\text { Whitney U }\end{array}$ & Sig. \\
\hline Students' & 0.647 & 0.104 & Vi-Chem-Lab & 43.120 & 1423.000 & 128.000 & 0.000 \\
motivation & 0.352 & 0.242 & Hands-on & 19.770 & 593.000 & & \\
Attention & 0.560 & 0.163 & Vi-Chem-Lab & 39.480 & 1303.000 & 248.000 & 0.001 \\
& 0.264 & 0.340 & Hands-on & 23.770 & 713.000 & & \\
Curiosity & 0.662 & 0.243 & Vi-Chem-Lab & 39.730 & 1311.000 & 240.000 & 0.000 \\
& 0.392 & 0.306 & Hands-on & 23.500 & 705.000 & & \\
Self-efficacy & 0.854 & 0.191 & Vi-Chem-Lab & 38.000 & 1254.000 & 297.000 & 0.004 \\
& 0.634 & 0.329 & Hands-on & 25.400 & 762.000 & & \\
Satisfaction & 0.558 & 0.167 & Vi-Chem-Lab & 43.050 & 1420.500 & 130.500 & 0.000 \\
& 0.203 & 0.290 & Hands-on & 19.850 & 19.850 & & \\
\hline
\end{tabular}

Table 8 describes significant differences in students' motivation (p-value $0.000<0.05$ ) toward chemistry between the ViChem-Lab and Hands-on groups with the favor on ViChem-Lab group. Each indicator of students' achievement covering attention, curiosity, self-efficacy, and satisfaction also signified a significant difference among the two groups. Thus, the ViChem-Lab in blended online learning mode can improve students' motivation towards chemistry.

Phrased differently, concerning the influence of ViChem-Lab in this research towards students' achievement was analyzed using the Independent T-test. Before the Independent T-test was performed, the test assumptions covering the normality and homogeneity tests were confirmed to be fulfilled. The data of students' achievement on the ViChem-Lab group (Sig. $0.348>0.05$ ) and the Hands-on group (Sig. $0.194>0.05$ ) were found to be 
normally distributed. The two groups were also found to be homogeny in terms of their achievement (Sig. $0.138>0.05$ ). The Independent T-test analysis findings that describe the significant differences in students' achievement toward chemistry in both groups were illustrated in Table 9.

\section{Table 9}

Independent Sample T Test Examining the Significance Differences on Students' Achievement

\begin{tabular}{lllllllllc}
\hline $\begin{array}{c}\text { Dependent } \\
\text { Variable }\end{array}$ & $\begin{array}{c}\text { Student } \\
\text { Group }\end{array}$ & Mean & $S D$ & df & t-value & Sig. & $\begin{array}{c}\text { Mean } \\
\text { Difference }\end{array}$ & $\begin{array}{c}\text { Std. Error } \\
\text { Difference }\end{array}$ & $\begin{array}{c}\text { Cohen's } \\
\boldsymbol{d}\end{array}$ \\
\hline $\begin{array}{l}\text { Students } \\
\text { achievement }\end{array}$ & Vi-Chem- & 0.757 & 0.058 & 61 & 2.473 & 0.016 & 4.430 & 1.791 & 0.091 \\
& Lab & & & & & & & & \\
\hline
\end{tabular}

From Table 9, it is proven that there was a significant difference in students' achievement among the ViChem-Lab and hands-on group (Sig. $0.016<0.05)$ with the favor of the ViChem-Lab group. It was also explained that ViChem-Lab in blended online learning contributes as much as $9.1 \%$ of the variance of students' achievement. Therefore, the experimental manipulation was significantly influenced by this research on students' motivation and achievement toward chemistry.

\section{Discussion}

The shift of the 21st-century learning system leads to integrating technology in teaching-learning instruction such as chemistry. Several factors influenced the quality of chemistry learning, but the most prominent one is through the learning media. It was supported by a study conducted by Eyler and Giles (2008) that describes the media used by the teacher brings the effectiveness of learning instruction. Learning media contributes to promoting the students to achieve learning objectives. Moreover, instructional learning media also potentially improves students' cognitive learning outcomes as the essential outcomes in chemistry learning.

In the chemistry learning activities, the laboratory work has the primary role in contributing to developing and understanding chemistry concepts (Elliot et al., 2008). The role of technology could be used as the media to visualize the abstractness of the chemistry concept. Thus, the ViChem-Lab should be a potential alternative media to supplement or replace of chemistry hands-on laboratory work activities. The ViChem-Lab is essential in order to support and motivate students in doing laboratory work. It also could develop students' thinking and understanding (Tatli \& Ayas, 2012). Moreover, the ViChem-Lab was interactive multimedia; thus, the students were engaged visually, 
auditory, and kinaesthetically, leading to an easier understanding of the chemistry concept. Kemp and Dayton (2002) suggested that interactive media makes the learning activities exciting and will be elaborating students' curiosity. Yet, in this research, the students show their high enthusiasm and effort to be focused on the learning activities using ViChem-Lab. Therefore, it leads to the great improvement of students' motivation and achievement in this research.

In terms of students' achievement, since the ViChem-Lab is a modern visualization media, it contributes to bridging the macro and micro concepts to learn the scientific and chemical concepts. The ViChem-Lab could set up students' conceptions, principal, process, and meaningful experience (Tatli \& Ayas, 2013). It also allows the students effortlessly to repeat the experimental simulation on their own; thus, they can conduct a deep analysis regarding the chemistry concept of electrolyte and non-electrolyte solution and redox reaction topic. As revealed by Shin et al. (2000) and Jeschke et al. (2010), ViChem-Lab could help the students understand the chemistry concepts. This learning method offers a joyful and meaningful learning environment (Ardac \& Akaygun, 2004; Jeschke et al., 2010). Hence, it significantly increases students' achievement after perceiving ViChem-Lab in the learning activities. The results of this research confirmed the previous research that the ViChem-Lab helps the students understand the nature of the concepts they learn that brings a better students' achievement (Shin et al., 2000; Jeschke, et al., 2010). For example, in doing the laboratory work about the ability of electrolyte solution in conducting electricity, the ViChem-Lab was visualized the concepts very well by providing the ionization of the electrolyte solution. Therefore, the students show significant improvement in understanding the chemistry concept.

Furthermore, the ViChem-Lab in this research was provided in blended online learning. Blended online learning offers a combination of face-to-face and online phase learning activities. The blended online learning integrates the variety of media and tools used in an online learning environment. In addition, it also combines the teaching-learning approaches with the bridge of technology. Since the ViChem-Lab student group enrolled in the blended online learning mode, they enrolled in the exact location of chemistry learning, either physical or digital. Hence, the chemistry learning activities were performed physically and digitally because the students were utilizing the ViChem-Lab media flexibly. This virtual learning environment could facilitate the teachers' work by differentiating learning content, monitoring students' learning outcomes, and giving feedback to students and their parents (Kondratavičienè, 2018). Yet for students, the blended online learning prepares the online discussion and assignment submission instead of the additional learning time. Thus, students enrolled in the ViChem-Lab group have extra learning time through the online phase of blended online learning that leads to enhancing students' achievement (Fitriyana et al., 2020).

On the other hand, assessing students' motivation is important to encourage students to choose and prepare for their future profession (Poteliūniené, 2018). The students' mo- 
tivation was affected by their attention, curiosity, self-efficacy, and satisfaction (Keller \& Kopp, 1987; Pečiuliauskienè, 2020; Dyrberg et al., 2016). As in this research, the implementation of ViChem-Lab was used to supplement the hands-on laboratory work activities. This research revealed that the ViChem-Lab has a significant influence on students' motivation to learn chemistry. In detail, the ViChem-Lab influenced the four aspects of students' motivation with the strongest until the most minor effects were found on selfefficacy, curiosity, attention, and satisfaction, respectively. Self-efficacy provides the most substantial controlled aspects of motivation after students experience ViChem-Lab. The previous work confirmed that the students had significantly improved their confidence in conducting laboratory work experiments through the presence of ViChem-Lab (Dyberg et al., 2016; Kolil et al., 2020). This finding suggests that the students felt better prepared and believed in their understanding of the experiment and the chemistry concept. The remarkable improvement of self-efficacy means the students believe in their capability towards chemistry teaching materials, and thus it improves students' achievement.

Moreover, students show their enthusiasm toward ViChem-Lab because it provides a new learning environment for them. This fact leads to increased curiosity and attention, which were significant in this research. Still, since the students showed a high enthusiasm, it also contributes to their satisfaction with the chemistry learning activities (Kintu, 2017).

\section{Conclusion and Recommendation}

The significant influence of ViChem-Lab in blended online learning mode on students' motivation and achievement toward chemistry has been examined. The implementation of ViChem-Lab in blended online learning was promising since it improves students' motivation and achievement toward chemistry. In detail, the ViChem-Lab influences the four indicators of students' motivation with the strongest effects found on selfefficacy, curiosity, attention, and satisfaction. Since self-efficacy was the most contributed factor, it implied the enhancement of students' achievement. The high strengthening of self-efficacy means the students believe in their capability towards chemistry teaching materials after perceiving ViChem-Lab in blended online learning mode. Thus, it brings the improvement of students' achievement. Hence, the use of ViChem-Lab in blended online learning should be emphasized to be further used in chemistry learning to promote students' motivation and achievement toward chemistry.

This study performed ViChem-Lab as the supplement of the hands-on laboratory. As a supplement to hands-on laboratory, students could improve their practical skills through the hands-on laboratory. They may develop their understanding of the concept of chemistry that is particularly abstract through the presence of ViChem-Lab. Therefore, another researcher interested in this topic is recommended to use and compare the 
effectiveness of ViChem-Lab in blended online learning as the replacement of a hands-on laboratory in future studies. Thus, the potential of ViChem-Lab in blended online learning as a supplement or replacement for the hands-on laboratory will contribute towards the new knowledge on the effectiveness of the use of virtual laboratory.

\section{Acknowledgements}

The authors gratefully acknowledge the Indonesian Directorate General of Higher Education (Kemenristekdikti-Indonesia) for funding through the "Tim Pascasarjana" research grant.

\section{References}

Abakumova, I. V., Bakaeva, I. A., \& Kolesina, K. Y. (2016). Technologies of initiating students into independent (self-guided) activity in supplementary distance learning. International Journal of Cognitive Research in Science, Engineering and Education, 4(2), 1-7. https://doi. org/10.5937/IJCRSEE1602001A

Akbas, A., \& Kan, A. (2007). Affective factors that influence chemistry achievement (motivation and anxiety) and the power of these factors to predict chemistry achievement-II. Journal of Turkish Science Education, 4(1), 10-19. https://www.tused.org/index.php/tused/article/ view/459/395

Augustinovič, A. (2019). Educational opportunities of natural science motivation for students with special educational needs: The viewpoint of natural science teachers. Pedagogy, 136(4), 141-152. https://doi.org/10.15823/p.2019.136.9

Ardac, D., \& Akaygun, S. (2004). Effectiveness of multimedia-based instruction that emphasizes molecular representations on students' understanding of chemical change. Journal of Research in Science Teaching, 41(4), 317-337. http://dx.doi.org/10.1002/tea.20005

Baragash, R. S., \& Al-Samarraie, H. (2018). Blended learning: Investigating the influence of engagement in multiple learning delivery modes on students' performance. Telematics and Informatics, 35(7), 2082-2098. https://doi.org/10. 1016/j.tele.2018.07.010

Bawaneh, A. K. A., Zain, A. N. M., Saleh, S., \& Abdullah, G. K. (2012). Using Herrmann whole brain teaching method to enhance students' motivation towards science learning. Journal of Turkish Science Education, 9(3), 3-22. http://tused.org/index.php/tused/article/view/436

Bidarra, J., \& Rusman, E. (2016). Towards a pedagogical model for science education: Bridging educational contexts through a blended learning approach. Open Learning: The Journal of Open, Distance and e-Learning, 32(1), 6-20. https:/doi.org/10.1080/02680513.2016.1265442 
Bolte, C., Streller, S., \& Hofstein, A. (2013). How to motivate students and raise their interest in chemistry education. In I. Eilks \& A. Hofstein (Eds.), Teaching chemistry: A study book (pp. 67-95). Sense Publishers. https://doi.org/10.1007/978-94-6209-140-5 3

Bozkurt, E. (2008). The effects on students' success of a virtual laboratory application prepared in the physics education. Unpublished PhD thesis. Selcuk University, Konya.

Calimag, J. N., Mugel, P. A., Conde, R. S., \& Aquino, L. B. (2014). Ubquitous learning environment using android mobile application. International Journal of Research in Engineering \& Technology, 2(2), 119-128. http://www.impactjournals.us/search.php

Coll, R. K., Ali, S., Bonato, J., \& Rohindra, D. (2005). Investigating first-year chemistry learning difficulties in the south pacific: A case study from Fiji. International Journal of Science and Mathematics Education, 4, 365-390. https://doi.org/10.1007/s10763-005-9007-6

Demirel, M., \& Turan, B. A. (2010). The effects of problem-based learning in achievement, attitude, metacognitive awareness and motivation. Hacettepe University Journal of Education, 38, 55-66.

Dyrberg, N. R., Treusch, A. H., \& Wiegand, C. (2016). Virtual laboratories in science education: Students' motivation and experiences in two tertiary biology courses. Journal of Biological Education, 51(11), 1-17. http://dx.doi.org/10.1080/00219266.2016.1257498

Elliot, M. J., Stewart, K. K., \& Lagowski, J. J. (2008). The role of the laboratory in chemistry instruction. Journal of Chemical Education, 85(1), 145-149. http://doi.org/10.1021/ed085p145

Eyler, J., Giles, D. E., \& Schmeide, A. (2008). A practitioner's guide to reflection in service-learning: Student voices and reflections. Vanderbilt University.

Ferrell, B., Phillips, M. M. \& Barbera, J. (2016). Connecting achievement motivation to performance in general chemistry. Chemistry Education Research and Practice, 17(4), 1054-1066. https:// doi.org/10.1039/C6RP00148C

Fitriyana, N., Wiyarsi, A., Ikhsan, J. \& Sugiyarto, K. H. (2020). Android-based-game and blended learning in chemistry: Effect on students' self-efficacy and achievement. Cakrawala Pendidikan, 39(3), 507-521. https://doi.org/10.21831/cp.v39i3.28335

Fitriyana, N., Wiyarsi, A., Sugiyarto, K. H., \& Ikhsan, J. (2021). The influences of hybrid learning with video conference and "chemondro-game" on students' self-efficacy, self-regulated learning, and achievement toward chemistry. Journal of Turkish Science Education, 18(2), 1-16.

Gendjova, A. (2007). Enhancing students' interest in chemistry by home experiments. Journal of Baltic Science Education, 6(3), 5-15. http://www.scientiasocialis.lt/jbse/?q=node/137

Guilford, J. P., \& Fruchter, B. (1998). Fundamental statistics in psychology and education (6th ed.). New York: McGraw-Hill, Inc.

Gulbinskienè, D., Masoodi., M., \& Šliogerienè, J. (2017). Moodle as virtual learning environment in developing language skills, fostering metacognitive awareness and promoting learner autonomy. Pedagogy, 127(3), 176-185. http://dx.doi.org/10.15823/p.2017.47

Güvercin, Ö., Tekkaya, C., \& Sungur, S. (2010). A cross age study of elementary students' motivation towards science learning. Hacettepe University Journal of Education, 39, 233-243. http://www.efdergi.hacettepe.edu.tr/english/abstracts/39/pdf/ÖZGE\%20GÜVERCİN.pdf 
Hake, R. R. (1998). Interactive-engagement versus traditional methods: A six-thousand-student survey of mechanics' test data for introductory physics course. American Journal of Physics, 66(1), 64-74. http://dx.doi.org/10.1119/1.18809

Hawkins, I., \& Phelps, A. J. (2013). Virtual laboratory vs. traditional laboratory: Which is more effective for teaching electrochemistry? Chemistry Education Research and Practice, 14, 516-523. https://doi.org/10.1039/c3rp00070b

Herga, N. R., \& Dinevski, D. (2014). Virtual laboratory in chemistry-experimental study of understanding, reproduction and aplication of acquired knowledge of subject's chemical content. Organizacija, 45(3), 108-116. https://doi.org/10.2478/v10051-012-0011-7

Jahjouh, Y. M. A. (2014). The effectiveness of blended e-learning forum in planning for science instruction. Journal of Turkish Science Education, 11(4), 3-16. https://doi.org/10.12973/ $\underline{\text { tused.10123a }}$

Jeschke, S., Richter, T., \& Zorn, E. (2010). Virtual labs in mathematics and natural sciences, Online Educa Berlin, http://www.ibi.tu-berlin.de/diskurs/veranst/online educa/oeb 04/ Zorn\%2520TU.pdf at 14.03.2020.

Keller, J. M., \& Kopp, T. W. (1987). An application of the ARCS model of motivational design. In C. M. Reigeluth (Ed.), Instructional theories in action: Lessons illustrating selected theories and models (pp. 289-320). Lawrence Erlbaum Associates, Inc. https://doi. org/10.4324/9780203056783-9

Kemp, J. E., \& Dayton, D. K. (2002). Planning and producing instructional media. New York: Harper \& Row Publisher.

Kintu, M. J., Zhu, C., \& Kagambe, E. (2017). Blended learning effectiveness: The relationship between student characteristics, design features and outcomes. International Journal of Educational Technology in Higher Education, 14(7), 1-20. https://doi.org/10.1186/s41239017-0043-4

Kolil, V. K., Muthupalani, S., \& Achuthan, K. (2020). Virtual experimental platforms in chemistry laboratory education and its impact on experimental self-efficacy. International Journal of Educational Technology in Higher Education, 17, 1-22. https://doi.org/10.1186/s41239-020$\underline{00204-3}$

Kondratavičienè, R. (2018). Individualization and differentiation of the content of primary education by using virtual learning environment "EDUKA class". Pedagogika, 130(2), 131-147. https://doi.org/10.15823/p.2018.27

Krathwohl, D. R. (2002). A revision of bloom's taxonomy: An overview. Theory into Practice, 41(4), 212-218. fhttps://www.depauw.edu/files/resources/krathwohl.pdf

Lalima, \& Dangwal, K. L. (2017). Blended learning: An innovative approach. Universal Journal of Educational Research, 5(1), 129-136. https://doi.org/10.13189/ujer.2017.050116

Latifah, Z., Ikhsan, J., \& Sugiyarto, K. H. (2018). Influence of virtual chemistry laboratory utilization (V-Lab) toward self-regulated learning. Journal of Physics: Conference Series, 1097, 012067. https://doi.org/10.1088/1742-6596/1097/1/012067 
Musawi, A. S. A. (2011). Blended learning. Journal of Turkish Science Education, 8(2), 3-8. http:// tused.org/index.php/tused/article/view/355/295

Pečiuliauskienè, P. (2020). School students' self-confidence in science and intrinsic motivation for learning science: Self-concept and self-efficacy approach. Pedagogy, 137(1), 138-155. https:// doi.org/10.15823/p.2020.137.8

Pečiuliauskiene, P., \& Belakoz, A. (2019). School students' motivation for learning sciences: how is it influenced by self-confidence in science and inquiry-based teaching approach? Pedagogy, 134(2), 121-134. https://doi.org/10.15823/p.2019.134.8

Poteliūniene, S. (2018). First-year pre-service physical education teachers' academic motivation and their satisfaction with academic studies. Pedagogy, 129(1), 234-249. https://doi. org/10.15823/p.2018.16

Priyambodo, E., Fitriyana, N., Primastuti, M., Artistic, A. D. (2021). The role of collaborative learning based STSE in acid base chemistry: Effects on students' motivation. Advances in Physics Research, 528, 253-263. https://dx.doi.org/10.2991/assehr.k.210305.037

Salta, K., \& Tzougraki, C. (2004). Attitudes toward chemistry among 11th grade students in high schools in Greece. Science Education, 88(4), 535-547. https://doi.org/10.1002/sce.10134

Sharma, B., Nand, R., Naseem, M., \& Reddy, E. V. (2019). Effectiveness of online presence in a blended higher learning environment in the Pacific. Studies in Higher Education, 45(8), 1547-1565. https://doi.org/10.1080/03075079.2019.1602756

Shin, D., Yoon, E. S., Park, S. J., \& Lee, E. S. (2000). Web-based interactive virtual laboratory system for unit operations and process systems engineering education. Journal Computers and Chemical Engineering, 24, 1381-1385. https://doi.org/10.1016/S0098-1354(00)00365-3

Sirhan, G. (2007). Learning difficulties in chemistry: An overiew. Journal of Turkish Science Education, 4(2), 2-20. http://www.tused.org.

Sokrat, H., Tamani, S., Moutaabbid, M., \& Radid, M. (2014). Difficulties of students from the faculty of science with regard to understanding the concepts of chemical thermodynamics. ProcediaSocial and Behavioral Sciences, 116, 368-372. http://dx.doi.org/10.1016/j.sbspro.2014.01.223

Solikhin, F., Sugiyarto, K. H., \& Ikhsan, J. (2019). The impact of virtual laboratory integrated into hybrid learning use on students' achievement. Jurnal Ilmiah Peuradeun, 7(1), 81-94. https:// journal.scadindependent.org/index.php/jipeuradeun/article/view/268/341

Spagnoli, D., Wong, L., Maisey, S., \& Clemons, T. D. (2017). Prepare, do, review: A model used to reduce the negative feelings towards laboratory classes in an introductory chemistry undergraduate unit. Chemistry Education Research and Practice, 18(1), 26-44. http://dx.doi. org/10.1039/c6rp00157b

Špernjak, A., \& Šorgo, A. (2017). Differences in acquired knowledge and attitudes achieved with traditional, computer-supported and virtual laboratory biology laboratory exercises. Journal of Biological Education, 52(2), 206-220. http://dx.doi.org/10.1080/00219266.2017.1298532

Stošić, L. (2015). The importance of educational technology in teaching. International Journal of Cognitive Research in Science, Engineering and Education, 3(1), 111-114. https://doi. org/10.23947/2334-8496-2015-3-1-111-114 
Suyatno, Wantini, Baidi, \& Amurdawati, G. (2019). The influence of values and achievement motivation on teacher professionalism at Muhammadiyah 2 high school Yogyakarta, Indonesia. Pedagogy, 133(1), 105-127. https://doi.org/10.15823/p.2019.133.6

Tatli, Z., \& Ayas, A. (2013). Effect of a virtual chemistry laboratory on students' achievement. Educational Technology \& Society, 16(1), 159-170. https://www.jstor.org/stable/ jeductechsoci.16.1.159

Treagust, D., Duit, R., \& Nieswandt, M. (2000). Sources of students' difficulties in learning chemistry. Educación Química, 11(2), 228-235. https://doi.org/10.22201/fq.18708404e.2000.2.66458

Volungevičienè, A., Duart, J., Naujokaitienė, J., Tamoliūnè, G., \& Greenspon, R. (2020). Teacher practices in using learning analytics to enhance learning in blended online studies. European Distance and E-learning Network (EDEN) Proceedings, 99-108. https://doi.org/10.38069/ edenconf-2020-ac0007

Wiersma, W., \& Jurs, S. G. (1990). Educational measurement testing. Needham Heights, MA, Allyn \& Bacon.

Wijayanti, R., Sugiyarto, K. H., \& Ikhsan, J. (2019). Effectiveness of using virtual chemistry laboratory integrated hybrid learning to students' learning achievement. Journal of Physics: Conference Series, 1156, 012031. https://doi.org/10.1088/1742-6596/1156/1/012031

Wiyarsi, A., Fitriyana, N., \& Ikhsan, J. (2019). Using technology in hydrocarbon topics: A profile on students' self-regulated learning. Journal for the Education of Gifted Young Scientists, 7(4), 961-972. http://dx.doi.org/10.17478/jegys.2018.82

Wiyarsi, A., Pratomo, H., \& Priyambodo, E. (2017). Chemistry learning: Perception and interest of vocational high school student of automotive engineering program. Proceedings of $3 \mathrm{rd}$ International Seminar on Science Education, 3(1), 359-366.

Zacharis, N. Z. (2015). A multivariate approach to predicting student outcomes in webenabled blended learning courses. The Internet and Higher Education, 27, 44-53. http://doi. org/10.1016/j.iheduc.2015.05.002

Zhikina, I., \& Portjanskaya, I. (2007). The use of opportunities of ICT in the techniques of teaching chemistry. Problems of Education in the 21st Century, 1, 120-124. http://oaji.net/ articles/2014/457-1392218743.pdf 


\title{
Virtuali chemijos laboratorija mišraus mokymosi režimu: itaka mokiniu motyvacijai ir pasiekimams
}

\author{
Jaslin Ikhsan ${ }^{1}$, Nur Fitriyana ${ }^{2}$, Zulham Arif ${ }^{3}$ \\ 1 Valstybinis Jogjakartos universitetas, Chemijos mokymo katedra, Matematikos ir gamtos mokslų fakultetas, \\ Colombo g. 1, ID-55281 Slemanas, Indonezija, jikhsan@uny.ac.id \\ 2 Valstybinis Jogjakartos universitetas, Chemijos mokymo katedra, Matematikos ir gamtos mokslų fakultetas, \\ Colombo g. 1, ID-55281 Slemanas, Indonezija, nur.fitriyana@uny.ac.id \\ 3 Valstybinis Jogjakartos universitetas, Chemijos mokymo studiju programos absolventas, Colombo g. 1, ID-55281 \\ Slemanas, Indonezija
}

\section{Santrauka}

Šiuo tyrimu buvo siekiama išanalizuoti virtualios cheminės laboratorijos mišraus mokymosi režimu įtaką mokinių motyvacijai ir pasiekimams mokantis apie elektrolitų ir ne elektrolitų tirpalus bei redokso chemijos reakcijas. Šiam tikslui pasiekti buvo atliktas kvazieksperimentas su nelygiavertėmis kontrolinėmis grupėmis prieš bandymą ir po jo.

Tyrime dalyvavo dvi dešimtokų klasės iš Indonezijos Jogjakartos Slemano regiono valstybinès vidurinès mokyklos. Viena klasė buvo eksperimentinė, jai buvo taikytas „Virtualios cheminès laboratorijos" mišrus internetinis mokymasis, o kontrolinè klasė mokèsi praktinejje laboratorijoje kontaktiniu būdu.

Duomenys apie mokinių motyvaciją buvo renkami naudojant mokinių motyvacijos klausimyną, o duomenys apie mokinių pasiekimus - naudojant mokinių pasiekimų testą. Duomenys buvo analizuojami naudojant aprašomąją statistiką, n-gain kategorijų analizę, MannWhitney U testą ir nepriklausomą imties t-testo metodą.

Šio tyrimo rezultatai parodè, kad virtualios cheminès laboratorijos naudojimas mišriame internetiniame mokyme daro didelę ịtaką mokinių motyvacijai ir pasiekimams chemijos srityje. Be to, virtuali cheminè laboratorija sužadino smalsumą, dėmesingumą, pasitenkinimą ir saviveiksmingumą. Tai yra keturi mokinių motyvacijos rodikliai, kurie gerina pasiekimus. Taigi, virtualaus mokymosi laboratorija turètų būti naudojama chemijos pamokose kaip potenciali mokymosi priemonė, skatinanti mokinių motyvaciją ir pasiekimus chemijos srityje.

Esminiai žodžiai: virtuali chemijos laboratorija, praktine laboratorija, mišrus mokymasis internetu, mokiniu motyvacija, mokiniu pasiekimai. 